\title{
Health productivity in macroeconomic level in Turkey: A Multi-level Causality Test approach
}

\author{
Fadime Çınar ${ }^{1 *}$, Halil Şengül ${ }^{2}$
}

${ }^{1}$ Sabahattin Zaim Üniversitesi Sağlık Bilimleri Fakültesi, Sağlık Yönetimi Istanbul, Turkiye

${ }^{2}$ Sabahattin Zaim Üniversitesi Sağlık Bilimleri Fakültesi, Sağlık Yönetimi Istanbul, Turkiye

DOI: https://doi.org/10.15520/ijmhs.v9i8.2674

Accepted 10 Aug 2019; Received 15 Jul 2019; Publish Online 20 Aug 2019

Reviewed By: Dr.

Daniel V.

Department: Medical

${ }^{\star}$ Corresponding author.

${ }^{\dagger}$ Email: fadime.cinar@izu.edu.tr.

\begin{abstract}
Although private health services have been common, it is known that health is a global public good, and it is related with global public expenditures. Recent studies shoved that productivity in health services is a main domain of government, nongovernmental organizations, and public sector. Thus, increase in productivity of health services provides efficient use of public goods. Moreover, public health services and productivity in health sector is a part of macroeconomic level. In this research, it is aimed to evaluate effects of macroeconomic indicators in health productivity. In the research, data collected from Turkey Statistics Institute (TUIK) for 2001-2016 were used to enlighten macroeconomic indicators and health productivity outcomes. According to results of the study, health expenditures and \% in GDP rates are causes for fertility rate $(\mathrm{p}<0.05)$. Moreover, health expenditures also causes for number of health organizations and number of birth $(\mathrm{p}<0.05)$. Number of birth causes price level indices $(\mathrm{p}<0.05)$. All these causality results show that their correlations are positive, since both $\mathrm{F}$ statistic level and data observations support positive correlations.
\end{abstract}

Key words: Health, macroeconomic, productivity

\section{INTRODUCTION:}

Increasing communication opportunities and development of globalization have changed concept and borders of health services (Beumer et al, 2018; Hanefeld, 2018; Ravindran, 2014; Schrecker et al, 2008). In the past, health was a manner of local and central governments within countries. On the other hand, globalization and "global public" approach argued that the health is a value of all humanity, and it has been started to taxed as "global public good" (Prentice, 2018; Hyndman and McKillop, 2018; Smith, 2014; London and Schneider, 2012). After this approach had been accepted by managing authorities, role of health services and productivity gained importance for international economic, financial and political areas. 
Since health is a public good, it is possible to manipulate health outcomes for political or other objectives (Chemouni, 2018; Schrecker et al, 2008; Kannan and Veazie, 2018; Okada, 2018; Rodriguez, 2018; Rosenberg et al, 2018). In elections, it may be argued that health outcomes are one of the most important factors affecting election results. In other countries having nondemocratic managing system, health outcomes are also important to provide affiliation of citizens. In short, it may be argued that quality and productivity of health services are two main issues of management, and public sector, even there may be a dense private health organizations.

Quality and productivity in health services is not only includes quantitative indicators, but it also includes qualitative aspects. Thus, it has vital importance to define isolated and reliable indicators to evaluate quality and productivity of health services. In this research, it was aimed to examine and define some macroeconomic indicators to evaluate productivity in health sector. Past studies in this area focused on hospital and branch based of other health outcome based analysis. In this research, macroeconomic level productivity in health sector was evaluated.

\section{METHOD:}

In the research, data were collected from Turkish Statistical Institute (TUIK) from 2001 to 2016. Collected data were examined. Unit root tests, Agumented fuller tests were used to define unite root tests. Granger causality test was used to define causality relations of variables. EVievs 7 and SPSS 17.0 for windows were used for analysis. All analysis were performed at \%95 CI level with an alpha 0.05 significance level.

\section{RESULTS:}

Health productivity indicators used in the analysis were given in the Table 1 .

\section{Table 1. Health productivity indicators used in the analysis}

\begin{tabular}{|c|c|c|c|c|c|c|c|c|c|c|}
\hline$\stackrel{\bar{\Xi}}{\beth}$ & 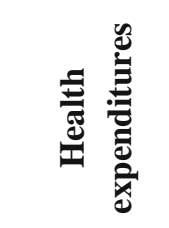 & $\begin{array}{l}\text { 它 } \\
\vdots \\
0\end{array}$ & 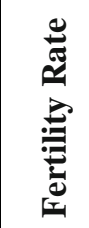 & 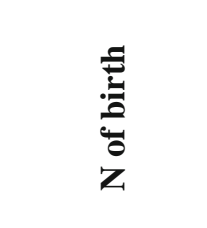 & 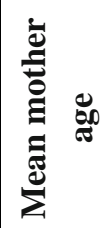 & 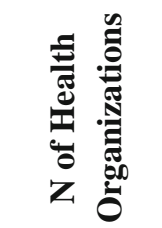 & 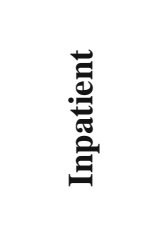 & 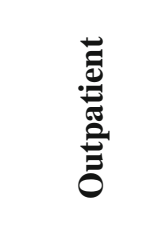 & ర్లే & 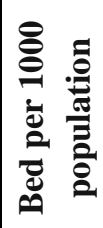 \\
\hline 2001 & $12.395,88$ & 5,10 & 2,38 & $1.323 .341,00$ & 26,20 & $10.581,00$ & $1.199,00$ & $9.382,00$ & $140.710,00$ & 2,14 \\
\hline 2002 & $18.773,94$ & 5,20 & 2,17 & $1.229 .555,00$ & 26,30 & $9.685,00$ & $1.156,00$ & $8.529,00$ & $164.471,00$ & 2,48 \\
\hline 2003 & $24.278,91$ & 5,20 & 2,09 & $1.198 .927,00$ & 26,50 & $9.183,00$ & $1.174,00$ & $8.009,00$ & $165.465,00$ & 2,46 \\
\hline 2004 & $30.020,85$ & 5,20 & 2,11 & $1.222 .484,00$ & 26,50 & $9.038,00$ & $1.217,00$ & $7.821,00$ & $166.707,00$ & 2,45 \\
\hline 2005 & $35.358,91$ & 5,20 & 2,12 & $1.244 .041,00$ & 26,50 & $8.870,00$ & $1.196,00$ & $7.674,00$ & $170.972,00$ & 2,48 \\
\hline 2006 & $44.068,68$ & 5,60 & 2,12 & $1.255 .432,00$ & 26,60 & $9.831,00$ & $1.203,00$ & $8.628,00$ & $174.342,00$ & 2,50 \\
\hline 2007 & $50.904,30$ & 5,80 & 2,16 & $1.289 .992,00$ & 26,70 & $11.839,00$ & $1.317,00$ & $10.522,00$ & $178.000,00$ & 2,52 \\
\hline 2008 & $57.740,00$ & 5,80 & 2,15 & $1.295 .511,00$ & 26,80 & $13.818,00$ & $1.350,00$ & $12.468,00$ & $183.183,00$ & 2,56 \\
\hline 2009 & $57.910,73$ & 5,80 & 2,10 & $1.266 .751,00$ & 26,90 & $15.205,00$ & $1.389,00$ & $13.816,00$ & $188.638,00$ & 2,60 \\
\hline 2010 & $61.677,60$ & 5,30 & 2,08 & $1.261 .169,00$ & 27,20 & $26.993,00$ & $1.439,00$ & $25.554,00$ & $200.239,00$ & 2,72 \\
\hline 2011 & $68.607,41$ & 4,90 & 2,05 & $1.252 .812,00$ & 27,30 & $27.997,00$ & $1.453,00$ & $26.544,00$ & $194.504,00$ & 2,60 \\
\hline 2012 & $74.188,71$ & 4,70 & 2,11 & $1.293 .884,00$ & 27,50 & $29.960,00$ & $1.483,00$ & $28.477,00$ & $200.072,00$ & 2,65 \\
\hline 2013 & $84.390,09$ & 4,70 & 2,10 & $1.295 .987,00$ & 27,70 & $30.116,00$ & $1.517,00$ & $28.599,00$ & $202.031,00$ & 2,64 \\
\hline 2014 & $94.749,51$ & 4,60 & 2,18 & $1.348 .413,00$ & 27,90 & $30.176,00$ & $1.528,00$ & $28.648,00$ & $206.836,00$ & 2,66 \\
\hline 2015 & $104.567,54$ & 4,50 & 2,15 & $1.333 .329,00$ & 28,00 & $30.449,00$ & $1.533,00$ & $28.916,00$ & $209.648,00$ & 2,66 \\
\hline 2016 & $119.755,78$ & 4,60 & 2,10 & $1.309 .771,00$ & 28,10 & $32.980,00$ & $1.510,00$ & $31.470,00$ & $217.771,00$ & 2,73 \\
\hline
\end{tabular}


As seen in the Table 1, health expenditures have been increased during evaluated period, whereas $\%$ in GDP of health expenditures has been decreased. This means that in a growing economy, health expenditures not increasing parallel to GDP. Number of in and outpatients, bed and birth have increased, but bed per population rate has insignificant changes. Fertility rate and number of birth shows that the population has fewer children than in the past. Overall evaluation shows that health expenditures and number of health organizations have increased, but still there have been some problems in health economy. During 15 year period, a comprehensive improvement must be performed, but there have not been enough improvements. Macroeconomic indicators used in the research were given in the Table2

Table 2. Macroeconomic indicators used in the analysis

\begin{tabular}{|c|c|c|c|}
\hline Year & $\begin{array}{c}\text { Purchasing Power Parity (USA } \\
\text { Dollar }=1,00)\end{array}$ & Price Level Indices (OECD - Total $=100)$ & Per Capita Reel GDP (USA Dollar) \\
\hline 2001 & 0,41 & 38,00 & $9.089,60$ \\
\hline 2002 & 0,59 & 44,00 & $9.207,89$ \\
\hline 2003 & 0,74 & 50,00 & $9.490,69$ \\
\hline 2004 & 0,79 & 55,00 & $10.749,72$ \\
\hline 2005 & 0,83 & 61,00 & $11.772,99$ \\
\hline 2006 & 0,84 & 59,00 & $13.497,95$ \\
\hline 2007 & 0,85 & 63,00 & $14.712,88$ \\
\hline 2008 & 0,88 & 64,00 & $15.901,08$ \\
\hline 2009 & 0,90 & 57,00 & $15.330,48$ \\
\hline 2010 & 0,92 & 60,00 & $17.281,33$ \\
\hline 2011 & 0,97 & 55,00 & $19.517,18$ \\
\hline 2012 & 1,02 & 56,00 & $20.549,29$ \\
\hline 2013 & 1,07 & 57,00 & $22.314,40$ \\
\hline 2014 & 1,10 & 52,00 & $24.158,81$ \\
\hline 2015 & 1,20 & 50,00 & $25.111,78$ \\
\hline 2016 & 1,30 & 49,00 & $25.655,47$ \\
\hline
\end{tabular}

Macroeconomic data show that purchasing parity of Turkey has increased during this 15 year period. However, the change is not statistically significant $(p>0.05)$. For price level indices, non stable or ordinary distribution has been performed. In other words, price level indices changed unstable structure. Per capita reel GDP rate has a stable and linear distribution in increasing trend. Ganger Causality test results for variables in the research were given in the Table 3 
Table 3: Ganger Causality test results for variables in the research

\begin{tabular}{|c|c|c|c|}
\hline Null Hypothesis: & Obs & F-Statistic & Prob. \\
\hline Health Expenditures \% in GDP $\rightarrow$ Fertility Rate & 14 & 8.51093 & $\mathbf{0 . 0 0 8 4}$ \\
\hline Fertility Rate $\rightarrow$ Health Expenditures $\%$ in GDP & & 0.10190 & 0.9041 \\
\hline Health expenditures $\rightarrow$ Fertility Rate & 14 & 5.39202 & 0.0289 \\
\hline Fertility Rate $\rightarrow$ Health expenditures & & 0.01614 & 0.9840 \\
\hline Mean Mother Age $\rightarrow$ Fertility Rate & 14 & 0.14490 & 0.8671 \\
\hline Fertility Rate $\rightarrow$ Mean Mother Age & & 0.93578 & 0.4273 \\
\hline Number of Birth $\rightarrow$ Fertility Rate & 14 & 0.83231 & 0.4659 \\
\hline Fertility Rate $\rightarrow$ Number of Birth & & 3.03059 & 0.0986 \\
\hline Number of Health Organizations $\rightarrow$ Fertility Rate & 14 & 2.70686 & 0.1201 \\
\hline Fertility Rate $\rightarrow$ Number of Health Organizations & & 0.11596 & 0.8918 \\
\hline Per Capita Reel GDP $\rightarrow$ Fertility Rate & 14 & 0.48143 & 0.6329 \\
\hline Fertility Rate $\rightarrow$ Per Capita Reel GDP & & 3.38585 & 0.0801 \\
\hline Price Level Indices $\rightarrow$ Fertility Rate & 14 & 0.03730 & 0.9635 \\
\hline Fertility Rate $\rightarrow$ Price Level Indices & & 0.13492 & 0.8755 \\
\hline Purchasing Power Parity $\rightarrow$ Fertility Rate & 14 & 0.05012 & 0.9514 \\
\hline Fertility Rate $\rightarrow$ Purchasing Power Parity & & 2.30106 & 0.1559 \\
\hline Health expenditures $\rightarrow$ Health Expenditures \% in GDP & 14 & 1.41807 & 0.2915 \\
\hline Health Expenditures \% in GDP $\rightarrow$ Health expenditures & & 5.33751 & 0.0296 \\
\hline Mean Mother Age $\rightarrow$ Health Expenditures \% in GDP & 14 & 1.86691 & 0.2098 \\
\hline Health Expenditures \% in GDP $\rightarrow$ Mean Mother Age & & 0.36609 & 0.7033 \\
\hline Number of Birth $\rightarrow$ Health Expenditures \% in GDP & 14 & 1.01664 & 0.3999 \\
\hline Health Expenditures \% in GDP $\rightarrow$ Number of Birth & & 0.79639 & 0.4803 \\
\hline Number of Health Organizations $\rightarrow$ Health Expenditures $\%$ in GDP & 14 & 1.67663 & 0.2405 \\
\hline Health Expenditures \% in GDP $\rightarrow$ Number of Health Organizations & & 3.81931 & 0.0630 \\
\hline Per Capita Reel GDP $\rightarrow$ Health Expenditures \% in GDP & 14 & 1.63047 & 0.2487 \\
\hline Health Expenditures \% in GDP $\rightarrow$ Per Capita Reel GDP & & 0.32784 & 0.7287 \\
\hline Price Level Indices $\rightarrow$ Health Expenditures \% in GDP & 14 & 3.67504 & 0.0681 \\
\hline Health Expenditures \% in GDP $\rightarrow$ Price Level Indices & & 2.77755 & 0.1150 \\
\hline Purchasing Power Parity $\rightarrow$ Health Expenditures $\%$ in GDP & 14 & 0.47698 & 0.6355 \\
\hline Health Expenditures $\%$ in GDP $\rightarrow$ Purchasing Power Parity & & 0.23900 & 0.7923 \\
\hline Mean Mother Age $\rightarrow$ Health expenditures & 14 & 1.77410 & 0.2241 \\
\hline Health expenditures $\rightarrow$ Mean Mother Age & & 1.47679 & 0.2788 \\
\hline Number of Birth $\rightarrow$ Health expenditures & 14 & 0.26453 & 0.7733 \\
\hline Health expenditures $\rightarrow$ Number of Birth & & 5.25150 & 0.0308 \\
\hline Number of Health Organizations $\rightarrow$ Health expenditures & 14 & 0.28242 & 0.7604 \\
\hline Health expenditures $\rightarrow$ Number of Health Organizations & & 18.7983 & 0.0006 \\
\hline Per Capita Reel GDP $\rightarrow$ Health expenditures & 14 & 0.45521 & 0.6482 \\
\hline Health expenditures $\rightarrow$ Per Capita Reel GDP & & 2.12775 & 0.1751 \\
\hline Price Level Indices $\rightarrow$ Health expenditures & 14 & 2.65354 & 0.1242 \\
\hline Health expenditures $\rightarrow$ Price Level Indices & & 5.56427 & 0.0267 \\
\hline Purchasing Power Parity $\rightarrow$ Health expenditures & 14 & 2.72719 & 0.1186 \\
\hline Health expenditures $\rightarrow$ Purchasing Power Parity & & 4.74821 & 0.0391 \\
\hline Number of Birth $\rightarrow$ Mean Mother Age & 14 & 1.18153 & 0.3502 \\
\hline Mean Mother Age $\rightarrow$ Number of Birth & & 2.03107 & 0.1871 \\
\hline Number of Health Organizations $\rightarrow$ Mean Mother Age & 14 & 1.19245 & 0.3472 \\
\hline Mean Mother Age $\rightarrow$ Number of Health Organizations & & 0.60518 & 0.5668 \\
\hline Per Capita Reel GDP $\rightarrow$ Mean Mother Age & 14 & 2.77431 & 0.1152 \\
\hline Mean Mother Age $\rightarrow$ Per Capita Reel GDP & & 0.95962 & 0.4190 \\
\hline Price Level Indices $\rightarrow$ Mean Mother Age & 14 & 1.57106 & 0.2599 \\
\hline
\end{tabular}


Mean Mother Age $\rightarrow$ Price Level Indices

Purchasing Power Parity $\rightarrow$ Mean Mother Age

Mean Mother Age $\rightarrow$ Purchasing Power Parity

Number of Health Organizations $\rightarrow$ Number of Birth

Number of Birth $\rightarrow$ Number of Health Organizations

Per Capita Reel GDP $\rightarrow$ Number of Birth

Number of Birth $\rightarrow$ Per Capita Reel GDP

Price Level Indices $\rightarrow$ Number of Birth

Number of Birth $\rightarrow$ Price Level Indices

Purchasing Power Parity $\rightarrow$ Number of Birth

Number of Birth $\rightarrow$ Purchasing Power Parity

Per Capita Reel GDP $\rightarrow$ Number of Health Organizations

Number of Health Organizations $\rightarrow$ Per Capita Reel GDP

Price Level Indices $\rightarrow$ Number of Health Organizations

Number of Health Organizations $\rightarrow$ Price Level Indices

Purchasing Power Parity $\rightarrow$ Number of Health Organizations

Number of Health Organizations $\rightarrow$ Purchasing Power Parity

Price Level Indices $\rightarrow$ Per Capita Reel GDP

Per Capita Reel GDP $\rightarrow$ Price Level Indices

Purchasing Power Parity $\rightarrow$ Per Capita Reel GDP

Per Capita Reel GDP $\rightarrow$ Purchasing Power Parity

Purchasing Power Parity $\rightarrow$ Price Level Indices

Price Level Indices $\rightarrow$ Purchasing Power Parity

\begin{tabular}{lll} 
& 5.64504 & $\mathbf{0 . 0 2 5 8}$ \\
14 & 0.90221 & 0.4394 \\
& $\mathbf{7 . 7 1 9 2 4}$ & $\mathbf{0 . 0 1 1 2}$ \\
14 & 2.54290 & 0.1332 \\
& 0.53258 & 0.6045 \\
14 & 3.27830 & 0.0852 \\
& 2.80725 & 0.1129 \\
14 & 0.66790 & 0.5365 \\
& $\mathbf{4 . 7 5 2 0 2}$ & $\mathbf{0 . 0 3 9 0}$ \\
14 & 2.39026 & 0.1470 \\
& 3.10607 & 0.0942 \\
$\mathbf{1 4}$ & $\mathbf{4 . 7 0 6 4 6}$ & $\mathbf{0 . 0 3 9 9}$ \\
& 1.36252 & 0.3041 \\
14 & 7.35163 & 0.0128 \\
& $\mathbf{4 . 6 8 3 8 7}$ & $\mathbf{0 . 0 4 0 3}$ \\
14 & 0.78331 & 0.4857 \\
& 1.00633 & 0.4033 \\
14 & 0.16751 & 0.8483 \\
& $\mathbf{5 . 5 8 8 3 0}$ & $\mathbf{0 . 0 2 6 4}$ \\
14 & 0.81417 & 0.4731 \\
& $\mathbf{4 . 3 8 2 8 6}$ & $\mathbf{0 . 0 4 6 9}$ \\
14 & 4.51230 & 0.0439 \\
& 2.91727 & 0.1055 \\
\hline \multirow{3}{*}{14}
\end{tabular}

According to Table 3, health expenditures and \% in GDP rates are causes for fertility rate $(\mathrm{p}<0.05)$. In addition, health expenditures also causes for number of health organizations and number of birth $(p<0.05)$. Number of birth causes price level indices $(p<0.05)$. All these causality results show that their correlations are positive, since both $\mathrm{F}$ statistic level and data observations support positive correlations.

\section{DISCUSSION:}

In this research, it is aimed to evaluate effects of macroeconomic indicators in health productivity. For this aim, data of Turkey during 2001-2016 were examined. In literature, there have been many researches on relationship between economic indicators and health state of the public (Schrecker et al, 2018; Ferreira et al, 2018; Wang et al, 2018; Arora et al, 2017; Tran et al, 2017Verikios et al, 2015). On the other hand, most of these studies focus on individual incomes and economic indicators. In this research, a multiple causality analysis has been performed, in order to enlighten role of health indicators and economic level.

Results of the study showed that health expenditures in Turkey have increased during examined period. Causality test results also showed that health expenditures have positive correlation and causality with fertility rates. In other words, increase in health expenditures causes increase in fertility rate. On the other hand, alternative hypothesis for health expenditure and fertility rate is not statistically significant. This means that health expenditure effects fertility rate, but fertility rate do not have statistically significant effect on health expenditures.

Another important result of the study is that health expenditures causes number of health organizations, whereas number of health organizations does not cause health expenditures. This means that increasing interest on health increases health organizations, but its main trigger is health expenditure increases. Similarly, 
health expenditures also cause price level indices and purchasing power parity.

\section{CONCLUSION:}

Results of the research shows that increasing health expenditures may be seen as a key factor for improving health sector and public health. In addition, it is seen from the research results that number of health organizations or fertility rate or numbers of births do not have a significant contribution on health expenditures. On the other hand, health expenditures affect these health indicators. As a result, it may be argued that health economy and improvements in health have a strong exogeneity. These exogeneities may include political environment, daily life expectations and routines.

Another important result of the study is that increase in health expenditures also increases fertility rates and number of births. On the other hand, increase in GDP or per capita GDP does not have an effect on fertility and birth rates. All of research results show that health expenditures have a key role in both macroeconomic and health parameters.

\section{REFERENCES:}

1. Arora S, Ramm CJ, Bahekar AA and Vavalle JP. Evaluating Health of Emerging Economies Through the Eyes of Heart Valve Disease in the Transcatheter Era. Global Heart, Volume 12, Issue 4, December 2017, Pages 301-304.

2. Beumer C, Figge L and Elliott J. The sustainability of globalisation: Including the 'social robustness criterion'. Journal of Cleaner Production, Volume 179, 1 April 2018, Pages 704-715.

3. Chemouni B. The political path to universal health coverage: Power, ideas and community-based health insurance in Rwanda. World
Development, Volume 106, June 2018, Pages 87-98.

4. Ferreira DC, Marques RC and Nunes AM. Economies of scope in the health sector: The case of Portuguese hospitals. European Journal of Operational Research, Volume 266, Issue 2, 16 April 2018, Pages 716735.

5. Hanefeld J. How does globalisation affect women's health?. The Lancet Global Health, Volume 6, Issue 1, January 2018, Pages e12-e13.

6. Hyndman $\mathrm{N}$ and McKillop D. Public services and charities: Accounting, accountability and governance at a time of change. The British Accounting Review, Volume 50, Issue 2, February 2018, Pages 143-148.

7. Kannan VD and Veazie PJ. Political orientation, political environment, and health behaviors in the United States. Preventive Medicine, Volume 114, September 2018, Pages 95-101.

8. London $\mathrm{L}$ and Schneider $\mathrm{H}$. Globalisation and health inequalities: Can a human rights paradigm create space for civil society action?. Social Science \& Medicine, Volume 74, Issue 1, January 2012, Pages 6-13.

9. Okada K. Health and political regimes: Evidence from quantile regression. Economic Systems, Volume 42, Issue 2, June 2018, Pages 307-319.

10. Prentice R. How surgery became a global public health issue. Technology in Society, Volume 52, February 2018, Pages 17-23.

11. Ravindran TKS. Poverty, food security and universal access to sexual and reproductive health services: a call for cross-movement advocacy against neoliberal globalization. 
Reproductive Health Matters, Volume 22, Issue 43, May 2014, Pages 14-27.

12. Rodriguez JM. Health disparities, politics, and the maintenance of the status quo: A new theory of inequality. Social Science \& Medicine, Volume 200, March 2018, Pages 36-43.

13. Rosenberg D, Kozlov V and Libman A. Political regimes, income and health: Evidence from sub-national comparative method. Social Science Research, Volume 72, May 2018, Pages 20-37.

14. Schrecker T, Birn AE and Aguilera M. How extractive industries affect health: Political economy underpinnings and pathways. Health \& Place, Volume 52, July 2018, Pages 135-147.

15. Schrecker T, Labonte R and De Vogli R. Globalisation and health: the need for a global vision. The Lancet, Volume 372, Issue 9650, 8-14 November 2008, Pages 1670-1676.

\section{AUTHOR BIOGRAPHY}

Fadime Çınar, Sabahattin Zaim Üniversitesi Sağlık Bilimleri Fakültesi, Sağlık Yönetimi Istanbul, Turkiye Halil Şengül, Sabahattin Zaim Üniversitesi Sağlik Bilimleri Fakültesi, Sağlık Yönetimi Istanbul, Turkiye
16. Smith R. Global Public Goods and Health. Encyclopedia of Health Economics, 2014, Pages 322-326.

17. Tran LD, Zimmerman FJ and Fielding JE. Public health and the economy could be served by reallocating medical expenditures to social programs. SSM - Population Health, Volume 3, December 2017, Pages 185-191.

18. Verikios G, Dixon PB, Rimmer MT and Harris AH. Improving health in an advanced economy: An economywide analysis for Australia. Economic Modelling, Volume 46, April 2015, Pages 250-261.

19. Wang B, Liu B, Niu H, Liu J and Yao S. Impact of energy taxation on economy, environmental and public health quality. Journal of Environmental Management, Volume 206, 15 January 2018, Pages 85-92. 